\title{
Teaching Children with Special Needs in Nigerian Regular Classes: Impact of Gender, Marital Status, Experience, and Specialty
}

\author{
Kingsley Chinaza Nwosu \\ University of the Free State, South Africa \\ https://orcid.org/0000-0002-8856-7938 \\ WP Wahl \\ University of the Free State, South Africa \\ https://orcid.org/0000-0002-1771-7863 \\ Hasina Cassim \\ University of Venda, South Africa \\ https://orcid.org/0000-0002-5168-8656 \\ Emmanuel Nkemakolam Okwuduba \\ University of Malaya, Malaysia \\ https://orcid.org/0000-0002-2158-3300 \\ Gloria Uzoamaka Nnaemeka \\ Nnamdi Azikiwe University, Awka \\ https://orcid.org/0000-0002-2623-7714
}

\begin{abstract}
This study investigated the impact of teachers' gender, marital status, years of experience, and specialty on their willingness to include children with special needs (CWSNs) in their classes. We adopted a crosssectional survey design. Using a convenience sampling technique, 316 teachers from 15 state-owned secondary schools in Awka South Local Government Area of Anambra State, Nigeria participated in this study. Data were analysed with mean, t-test, and ANOVA. Findings showed that teachers were willing to include CWSNs in their classes, and only teachers' specialty showed a significant impact on teachers' willingness to teach CWSNs. It was concluded that aspects of the teacher sociodemographic variables that may affect their willingness to include CWSNs are those that could influence their competence. Limitations of studies were highlighted.
\end{abstract}

Keywords: socio-demographic variables; special needs; inclusive education; regular classes 


\section{Introduction}

Diversity tolerance in classrooms has been advocated in current literature on inclusive education. One of the most preferred approaches to respecting individual needs and ensuring optimal development of all learners in classrooms is the inclusive education approach (Dea \& Negassa, 2019; Greene, 2017; Oladele, Ogunwale, \& Dafwat, 2016), given its benefits to both typically and atypically developing students (Cate et al., 2018). Underlying this perspective is the fact that schools necessarily are places for enhancing an individual's potential by ensuring equal educational opportunities (Chao et al., 2017). However, there is a perception that inclusive education, in many nations, is not adequately implemented, due to diverse conceptual interpretations (Braunsteiner \& MarianoLapidus, 2014; Dudley-Marling \& Burns, 2014; Global Partnership for Education, 2018; Schuelka \& Johnstone, 2011). This has led to the exclusion of vulnerable students from regular classrooms.

One of the factors that have bolstered the exclusivity of children with special needs (CWSNs) in regular classes is the teacher factor. Teachers have been found to argue that the inclusion of children with disabilities in their classes can undermine their productivity (Greene, 2017). Many factors are associated with teachers' non-receptivity of CWSNs in regular classes, namely the challenges posed by trying to provide education that could satisfy diverse individual needs (Limaye, 2016), teachers' perceived competence (Cate et al., 2018), institutional challenges such as weak policies and legislative challenges (Unachukwu \& Nwosu, 2019), cultural beliefs (Eskay, Eskay \& Uma, 2012), and teachers' attitude towards inclusion (Eskay, Eskay \& Uma, 2012; Obisesan, 2020). These five aspects concerning the teacher factor are important, because they highlight the current challenges facing inclusive education in Nigeria.

The Nigerian government is a signatory to several international agreements/arrangements that support inclusive education (Obisesan, 2020; Unachukwu \& Nwosu, 2019). However, predominant in the Nigerian context is the integration of CWSNs in regular classes (Oluremi, 2015a) - a position that does not always support fully inclusive educational practices. According to Oluremi (2015b), CWSNs in Nigeria may be rejected by some teachers because they lack the requisite training and the confidence to handle them. Training and experiences of teachers have been noted as crucial in the implementation of inclusive educational practices (Oluremi, 2015b), since these factors are likely to affect the attitude of teachers towards inclusionary practices in regular classes.

This link between training and experiences and the attitude of teachers is important because teachers are seen as pivotal in the implementation of inclusive education (Cate et al., 2018). Given this vital role, there is a growing research interest to understand factors that impact the receptivity of CWSNs by teachers (Cate et al., 2018; Gilor \& Katz, 2018; Low, Ng, Hui \& Cai, 2019). However, these studies mostly concentrate on the teachers' attitudes, self-belief systems, and subjective norms concerning inclusive practices (Gilor \& Katz, 2018; Low et al., 2019). It appears that the socio-demographic characteristics of teachers have not been fully considered in efforts to understand their willingness to include CWSNs 
in regular classes. These shortcomings in the existing body of literature make it difficult to derive any concrete generalization about how different variables concerning the teacher could influence inclusive educational practices, especially in a developing context like the Nigerian society. In line with the research finding of Dea and Negassa (2019), and Dev and Kumar (2015), we consider sociodemographic variables - such as gender, experience, and the specialty of the teacher - as crucial to teacher disposition to inclusive education. In a bid to address the limitations in current research, and contribute to knowledge regarding teachers' willingness to include CWSNs in Nigerian regular classrooms, we investigated how gender, marital status, level of experience, and specialty of teachers influence their receptivity to CWSNs. We believe the findings of this study will inform policies on training and retraining of teachers for effective inclusive educational practices and avoidance of rejection of CWSNs in regular classes. Practitioners could tailor-make interventions (training programmes) to take into consideration the unique needs and dispositions of regular teachers so that they will be willing to teach and provide emotional and adaptive support to CWSNs. It is clear that training teachers without taking into consideration their individual experiences, exposures, prior learning, gender, and marital status may be counter-productive, as literature is replete with evidence that teachers' socio-demographic variables impact their teaching effectiveness.

\section{Literature Review}

In this section, we report on a review of the education of CWSNs in the Nigerian context, to establish what the efforts to implement inclusive education entailed, and to identify factors impacting its effective implementation. Thereafter, we endeavoured to understand how teacher socio-demographic variables could be linked to teacher inclusive education practices, identifying existing gaps. Hence, the literature review is organized in the following sub-sections:

\subsection{Educating CWSNs in the Nigerian Context}

Researchers have noted that Nigeria has not met its obligation for full-inclusive education (Oluremi, 2015b; Unachukwu \& Nwosu, 2019). Various factors have impeded the implementation of inclusive education in Nigeria, such as sociocultural issues like the belief that disability has to do with curses and punishment from the gods (Eskay et al., 2012). These cultural beliefs affect teachers' attitudes towards CWSNs and constrain policy implementation with regard to the effective education of CWSNs (Eskay et al., 2012; Obisesan, 2020). Other factors that have mitigated against proper inclusion of CWSNs in regular classes include the following: inadequate adaptive facilities (Oluremi, 2015a), negative social attitude, unfriendly school environment, inadequate funding, inadequate human resources and training for teachers, lack of awareness of inclusive education, and policy and legislative issues (Adebisi et al., 2014; Onukwufor \& Martins, 2017). The fact that these factors have been allowed to strain the effective implementation of inclusive education in Nigeria, recently has raised questions about the prioritization thereof. 
Concerns about the prioritization of inclusive education have a bearing on the general failure to implement relevant policies, perceived as deficient, amidst a sub-optimal school system. Igbo et al. (2014), for instance, place the failure to educate CWSNs efficiently and inclusively in Nigeria against the backdrop of even children without special needs not having been adequately provided with quality education. This is why most challenges undermining general education in Nigeria also are found in special needs education but at a very disturbing rate (Igbo et al., 2014). Thus, the issue of sub-optimal education in the general school system seems to be intensified when it comes to the education of CWSNs. Though there have been concerted efforts globally to educate all persons, notwithstanding their unique characteristics in an inclusive setting, this noble idea has failed to be realized in Nigeria. Furthermore, although Nigeria has policies that spell out the need for inclusive education, researchers have noted deficiencies in the policy framework and the legislative provisions (Unachukwu \& Nwosu, 2019). This has perpetuated segregation and constrained Nigeria from implementing integration arrangements in educating CWSNs. Therefore, the majority of CWSNs are not educated in an inclusive education setting. Hence, it becomes pertinent to ascertain teacher factors that could impact their willingness to include children with disabilities in their regular classes. In this regard, teachers' sociodemographic variables in inclusive education practices are vital.

\subsection{Teachers' Socio-Demographic Variables and Inclusive Education Practices}

Understanding the impact of teacher demographic variables on teacher instructional practice, effectiveness, and student outcome - in both regular and special classes - has attracted the attention of researchers, specifically over the past ten years (Amadi \& Allagoa, 2017; Dea \& Negassa, 2019; Efanga, Ikpe \& Idante, 2014). One of the reasons that could be adduced for expending these research efforts is the fact - underpinned by a significant body of literature - that individuals' behaviours are affected by their social and biological attributes (Abdullahi, 2019; VanderStel, 2014). Abdullahi (2019:3) elaborately conceptualized socio-demographic variables as "the sociological and demographic attributes acquired by an individual(s) in a population that determine his/her socio-demographic positions or niches, socio-demographic roles, as well as the correlating socio-demographic advantages he/she attains and succeeds". The notion of socio-demographics includes several variables such as gender, age, marital status, income, education, family, ethnicity, religion, and so forth (Abdullahi, 2019; Rughinis \& Huma, 2015). For teacher education research, it could be conceptualized as attributes that demonstrate the socio-demographic positions of the teacher.

Researchers also have demonstrated how socio-demographic variables impact teacher retention and willingness to stay in the profession (Efanga et al., 2014), effectiveness in classroom management (Amadi \& Allagoa, 2017), and students' academic/literacy development (Ellis, 2011). Studies that concentrated on special needs education reported on teachers' socio-demographic features, such as teachers' years of experience, specialty, teaching area, age, pre- and in-service diversity training, and gender, which impact their inclusive educational practices, perspectives, self-efficacy, and attitudes (Boyd, 2017; Dea \& Negassa, 2019; Dev \& Kumar, 2015; LaVergne et al., 2012; Shaukat, 2012). In their study, for example, 
LaVergne et al. (2012) demonstrated how Texan agricultural education teachers' teaching area, ethnicity/race, gender, and school setting (rural, suburban, and urban) significantly impacted their perceptions about, and barriers and solutions to problems hampering the smooth move to inclusive education in an agricultural education programme. In the same vein, Shaukat (2012) found that the following factors accounted for significant mean differences in teacher self-efficacy in inclusive education: the type of school teachers are trained to teach at, the nature of their own educational programmes (B.Ed. general/special education, or M.Ed. general/special education), their level of training, and their experience in teaching CWSNs.

Furthermore, Dev and Kumar (2015) found that teachers' gender, age, and educational level accounted for significant differences in their perception of the integration of children with learning disabilities (CWLDs) in regular classes, while teaching experience and teaching field made no significant differences in their perception. What was interesting was that they reported that female teachers were more favourable towards integrating and more patient with CWLDs than their male counterparts. Teachers who were older than forty years and those with postgraduate qualifications showed a more positive inclination to integrating CWLDs in their regular classes. Song, Sharma and Choi (2019) also found that the completion of a compulsory course in special and inclusive education improved pre-service teachers' inclusive self-efficacy, intentions, concerns, and attitude. This shows that experience and exposure to rudiments in inclusive education can impact teachers' competence belief systems. It could, therefore, be inferred from the literature that, since perceptions of teachers on inclusive education could be impacted by socio-demographic variables, teachers' willingness to include CWLDs in regular classes also could be impacted by such variables. Therefore, as Nigeria is making advances to full inclusive education, understanding teacher socio-demographic variables that could impact the receptivity of CWSNs in the Nigerian context becomes pertinent. It is this gap in the literature that the present study intended to close.

\section{Theoretical Model}

Studies have indicated that a large number of factors impact the effective implementation of inclusive education (Adebisi et al., 2014; Eskay, 2012; Oluremi, 2015b; Onukwufor \& Martins, 2017; Unachukwu \& Nwosu, 2019). Prominent among these factors in the implementation of inclusive education of CWSNs is the teacher factor. Literature has shown that several studies have been conducted on teacher attitude to, and belief system on the inclusion of CWSNs in their regular classes. We also conceptualized that teacher socio-demographic variables such as teachers' gender, marital status, experience, and specialty will impact their willingness in teaching CWSNs, given that behaviours are reflections of social and biological characteristics (Abdullahi, 2019; VanderStel, 2014). This is framed based on previous work that associated teacher inclusive education practice for children with visual impairment with teacher socio-demographic variables (Dea \& Negassa, 2019). We extended this to general inclusive education practice within the scope of willingness to teach, and to provide emotional and adaptive support to CWSNs in regular classrooms. This is diagrammed in Figure 1 below: 


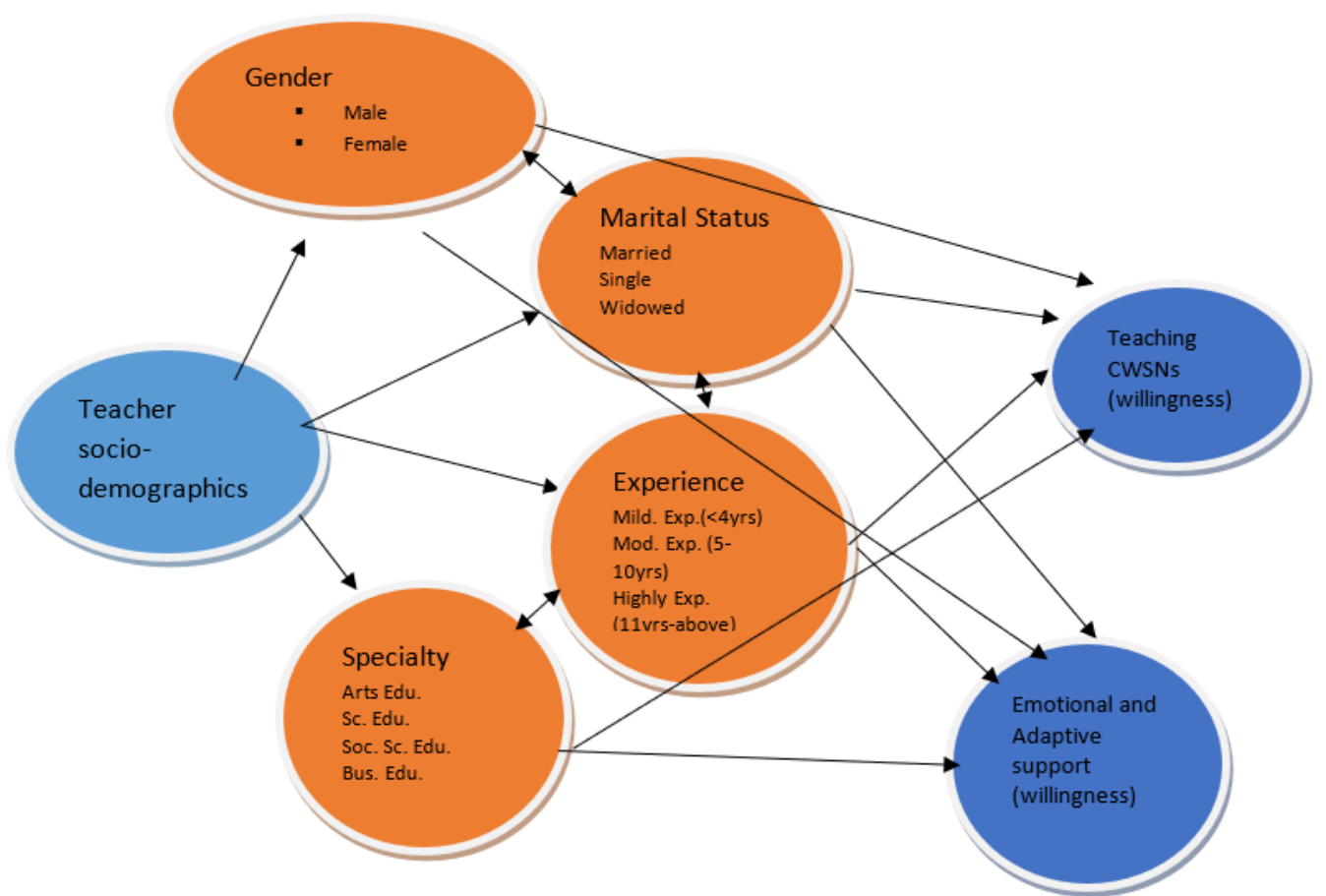

Figure 1: Conceptual Framework of Teacher Demographic Variables and Willingness to Include CWSNs in Regular Classes

\section{Objective of the study}

With the study we aimed to evaluate teachers' willingness to include CWSNs in their regular classes and to determine how their socio-demographic characteristics impact their willingness to include them in regular classes. This arises given that both the biological and sociological background of an individual could affect his behaviour. To inform policies and teacher training for effective inclusive educational practice in Nigeria, understanding the impact of teacher socio-demographic variables on their willingness to include CWSNs in their regular classes deserved to be studied. Regarding the willingness to include CWSNs in regular classes, we investigated teachers' willingness to teach them as well as their willingness to provide emotional and adaptive support to CWSNs. Our specific objectives, therefore, were to:

a) Investigate the willingness of teachers to teach CWSNs and provide them with emotional and adaptive support in their regular classes; and

b) Determine the impact of teachers' gender, marital status, experience and specialty on their willingness to teach CWSNs and provide them with emotional and adaptive support in their regular classes.

\subsection{Research question and hypothesis}

For a proper guide for the investigation, one research question was posed while a hypothesis was tested at 0.05 level of significance. Our research question was:

To what extent are teachers, in their diversity, willing to teach CWSNs and provide them with emotional and adaptive support in the regular classes? 
The hypothesis was:

Ho: Teachers' gender, marital status, years of experience, and specialty make no significant difference to their willingness to teach CWSNs and provide them with emotional and adaptive support in their regular classes.

H1: Teachers' gender, marital status, years of experience, and specialty make significant difference to their willingness to teach CWSNs and provide them with emotional and adaptive support in their regular classes.

\section{Method}

To understand the impact of teachers' demographic characteristics on their willingness to include CWSNs in regular classes, the researchers adopted the quantitative research paradigm as an approach to the investigation. This section is organized under research design, participants, instrument, method of data collection, and analysis.

\subsection{Research design}

We used a cross-sectional survey research design. Through the cross-sectional survey we aimed at determining the behavioural characteristics prevalent among a population by sampling a cross-section of the population at a point in time (cf. Fraenkel \& Wallen, 2000; Stockemer, 2019). We wanted to understand the overall picture of how willing teachers were to include CWSNs in their regular classes, hence the need for a design that would enable us to sample across the population. We collected data with the intention of possible generalization of the findings to the population.

\subsection{Participants}

The sample for our study comprised 316 teachers in public schools in Awka South Local Government Area of Anambra State, Nigeria. Teachers who were employed by government and those employed by Parent-Teachers Associations (PTAs) were sampled for the study. National Youth Service Corps members and student teachers who were doing their service year in the sampled schools were not included in the study. The convenience sampling technique was used, but we did not merely select available teachers, but also teachers who gave their consent after we had explained the essence of the study to them. The researchers visited the individual schools and approached the teachers in the staff rooms. Available teachers were handed the questionnaire. Some of the teachers reported that they were busy at the time but made appointments with the researchers to complete the questionnaires. When we revisited the schools, teachers who had not been available during the previous visit were approached and given the questionnaire to complete. We distributed 317 copies of the questionnaire in 15 public schools sampled for the study. Three hundred and sixteen teachers completed the questionnaire; thus one teacher dropped out of the study. The sample characteristics of our respondents are tabulated in Table 1: 
Table 1: Respondents' Characteristics

\begin{tabular}{llll}
\hline Variable & Characteristics & Number & Percentage \\
\hline Gender & Female & 247 & $79.4 \% ?$ \\
& Male & 64 & $20.6 \%$ \\
Marital Status & Married & 190 & $61.1 \%$ \\
& Single & 121 & $38.9 \%$ \\
\multirow{2}{*}{ Teaching Experience } & Widowed & 0.00 & $0 \%$ \\
& Mildly experienced (Less than 4 yrs.) & 88 & $35.2 \%$ \\
& Moderately experienced (5-10yrs) & 97 & $38.8 \%$ \\
Teachers' Academic & Highly Experienced (11 yrs. and more) & 65 & $26.0 \%$ \\
Qualifications & NCE & 25 & $8.9 \%$ \\
\multirow{2}{*}{ Area of Specialization } & Degree & 241 & $80.6 \%$ \\
& Master's Degree \& PhD & 33 & $11 \%$ \\
& Arts Education & 88 & $28.9 \%$ \\
& Social Science Education & 72 & $23.7 \%$ \\
& Science Education & 110 & $32.2 \%$ \\
& Business Education & 34 & $11.2 \%$ \\
\hline
\end{tabular}

The majority of the participating teachers were female (79.4\%), and more than half of them were married. Regarding experience, $26 \%$ had more than ten years' experience while $35.2 \%$ could not really be regarded as experienced teachers as they had less than five years' teaching experience. The results indicated that most teachers' highest academic qualification was a first degree $(80.6 \%)$, while $11 \%$ had master's and $\mathrm{PhD}$ degrees and the remaining 8.9\% were NCE (National Certificate in Education) holders. With regard to their field of specialty it was found that the sciences topped the list $(36.2 \%)$, followed by arts and social sciences $(28.9 \%$ and $23.7 \%$ respectively), while only $11.2 \%$ specialised in business education.

\subsection{Instruments}

The data collection instrument used was an integrated version of the Teacher Willingness to Teach Challenging Children Questionnaire (TWTCCQ) (Low et al., 2019) and the behavioural component of the Teachers' Multidimensional Attitude towards Inclusive Education Scale (TMATIES) (Mahat, 2008). We integrated these instruments to broaden the concept in such a way to include elements that had a bearing on both teaching and the provision of emotional and adaptive structures. Therefore, we referred to the questionnaire as the 'Teacher Willingness to Include CWSNs Questionnaire (TWICWSNsQ)'. We conducted an exploratory factor analysis (EFA) on the questionnaire to determine the underlying structures of the ten items in the instrument. Missing data were deleted listwise, the Kaiser-MeyerOlkin (KMO) measure was .882, the Bartlett test of sphericity was significant at 0.000 , showing that running an EFA on the items was justifiable given that they adequately correlated. The initial communalities ranged between .331 and 0.599 . Rotation showed the first factor accounted for $25.64 \%$ of the variance, the second factor accounted for $21.21 \%$. The range of the factor loadings is between 0.521 and 0.737. Factor 1 is for teaching support for CWSNs while factor 2 is for emotional and adaptive support. The internal consistency index using the Cronbach Alpha coefficient indicated that the first cluster has a .78 index, while the second cluster has a .83 reliability index. 


\subsection{Data Collection and Analysis}

We distributed the data collection instrument among teachers in public schools through the direct delivery technique. We visited the schools and explained to the teachers the essence of the research, whereafter we sought their consent to participate in the study. Participants were assured of confidentiality, as no provision was made on the questionnaire for teachers' names or staff identification numbers. They also were informed explicitly that they could leave the study if and when they deemed it fit. Those who consented to participate in the study were given copies of the questionnaire to complete.

Data were analysed using the IBM SPSS, version 26. Missing values were handled by default in SPSS. At the data entering stage, missing values were coded 999 . The main analysis was preceded by the testing of statistical assumptions such as a normality test and homogeneity of variances and handling of missing data. Missing data were deleted listwise by SPSS default. The Shapiro-Wilk test showed that the distributions in the two clusters were significant, $\mathrm{p}<.05$, while Levene's test showed that all the distributions were non-significant, $\mathrm{p}>.05$, indicating that variances were homogenous. Given the large sample size and that variances in distributions were homogenous, we continued our analysis with a t-test and analysis of variance (ANOVA) statistics. Violation of normality assumption has been shown to cause no harm in t-test analysis (Rochon, Gondan \& Kieser, 2012). The results of the normality test are presented in Table 2 and Figures 2-5 below.

Table 2: Tests of normality on teachers' willingness to include CWSNs in regular classes

\begin{tabular}{lr|r|r|r|r|r}
\hline & \multicolumn{3}{c}{ Kolmogorov-Smirnova } & \multicolumn{3}{c}{ Shapiro-Wilk } \\
& Statistic & Df & \multicolumn{1}{c|}{ Sig. } & Statistic & \multicolumn{1}{c}{ Df } & \multicolumn{1}{c}{ Sig. } \\
\hline $\begin{array}{l}\text { Willingness to teach } \\
\text { children }\end{array}$ & .155 & 314 & .000 & .954 & 314 & .000 \\
\hline $\begin{array}{l}\text { Willingness to provide } \\
\text { emotional and adaptive } \\
\text { support }\end{array}$ & .131 & 314 & .000 & .951 & 314 & .000 \\
\hline
\end{tabular}

a. Lilliefors Significance Correction

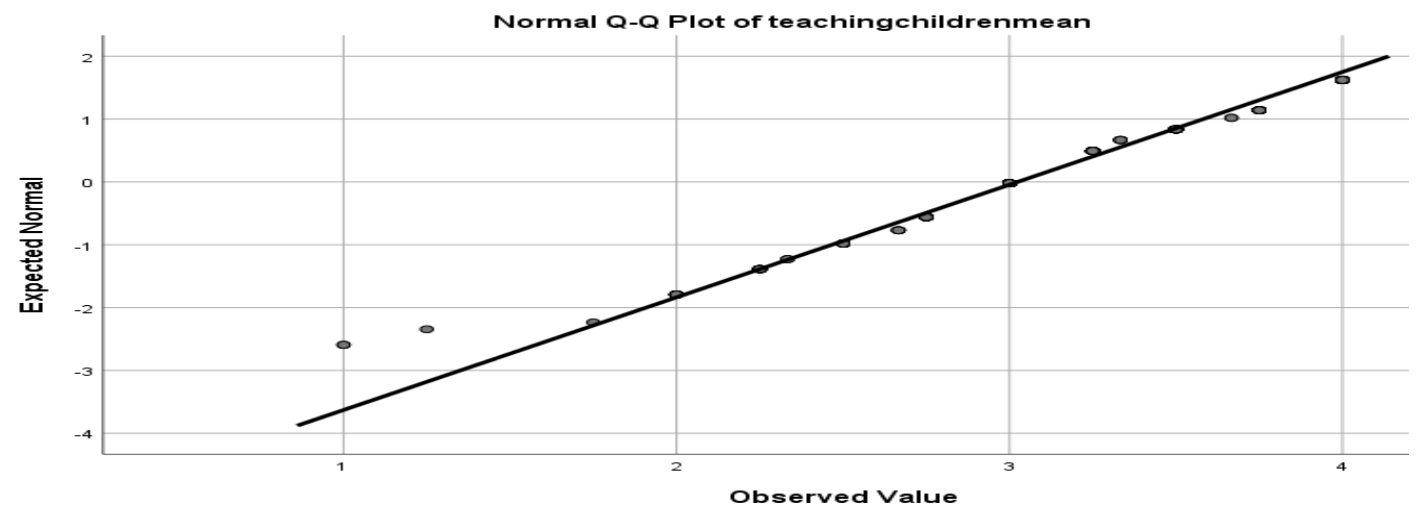

Figure 2: Normal Q-Q Plot of teaching CWSNs 


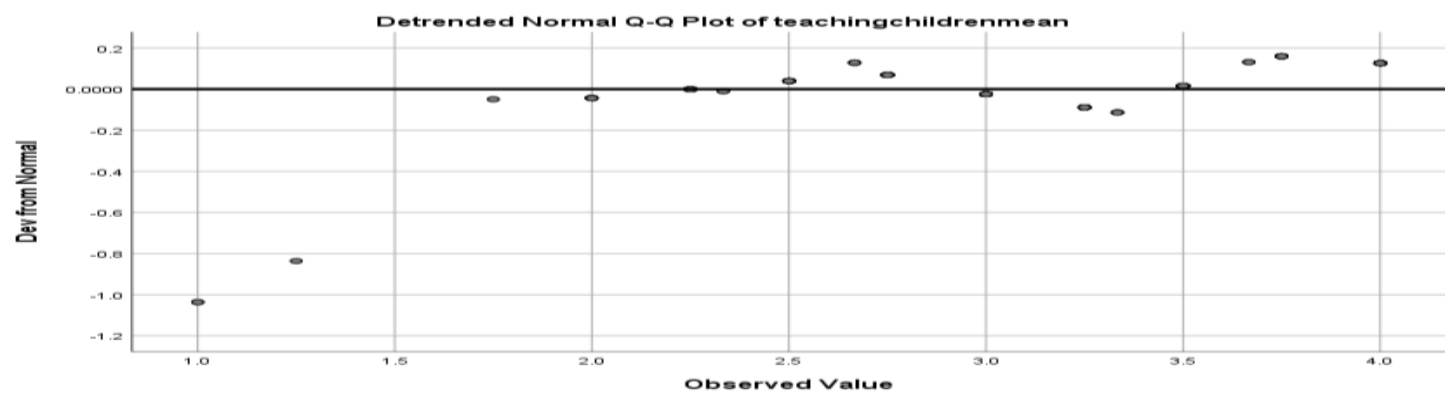

Figure 3: Detrended Normal Plot of Teaching CWSNs

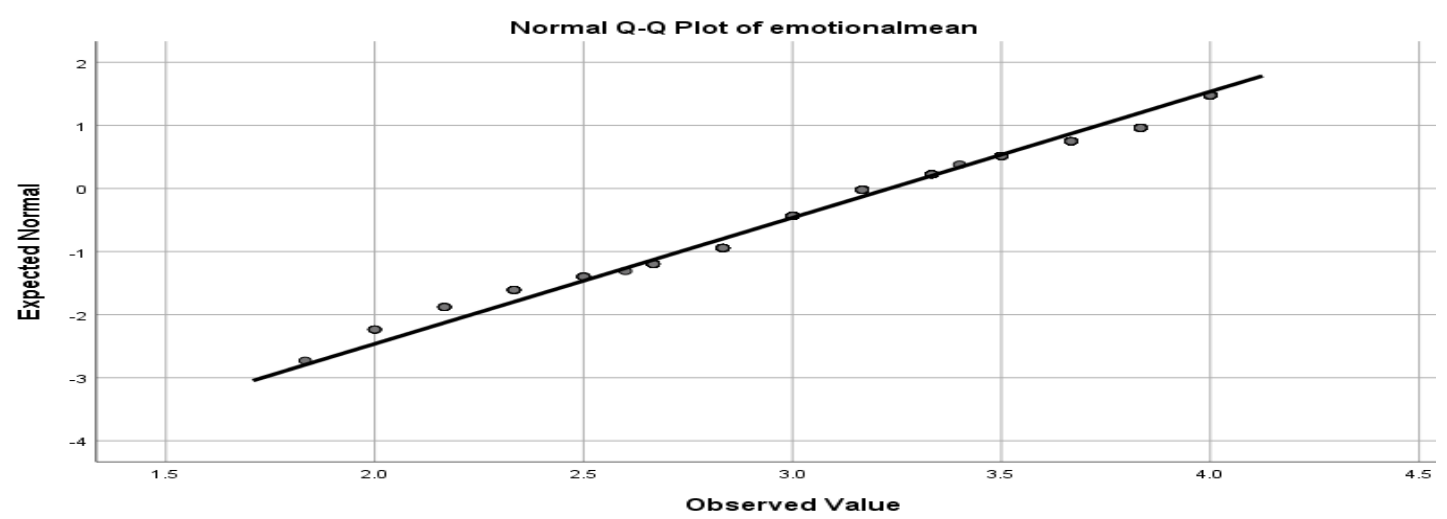

Figure 4: Normal Q-Q Plot of Provision of Emotional and Adaptive Support for CWSNs

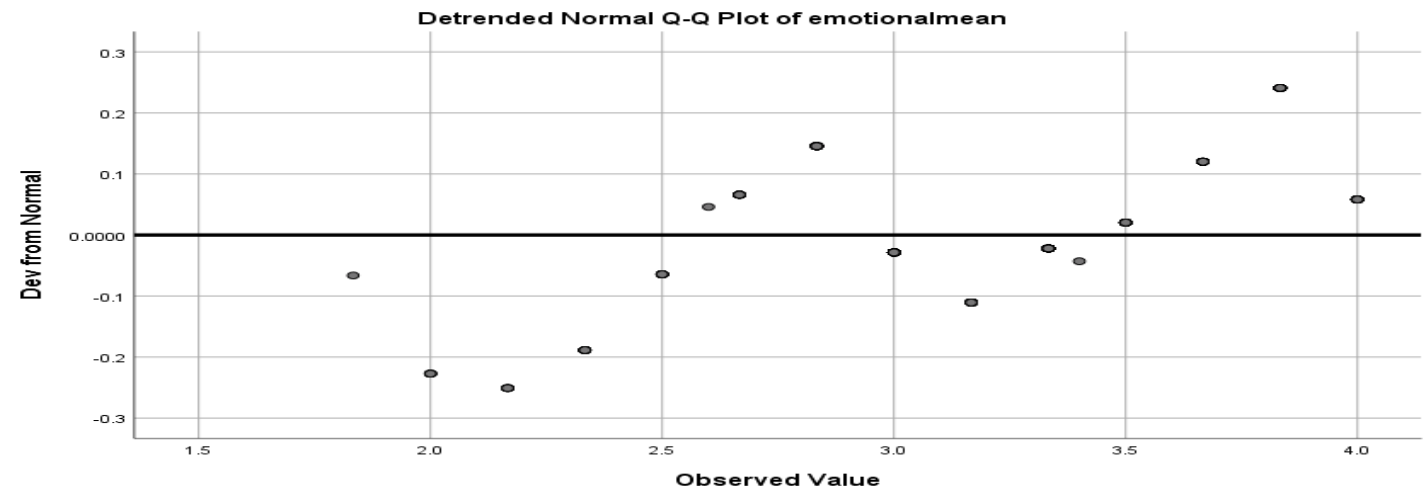

Figure 5: Detrended Normal Plot of Provision of Emotional and Adaptive Support for CWSNs 


\section{Results}

The results of the data analyses are provided in the tables and figures below, each followed by a brief discussion.

Table 3: Item by Item Analysis of Teachers' Mean Responses on their Willingness to Teach and Provide Emotional and Adaptive Supports to CWSNs

\begin{tabular}{|c|c|c|c|c|c|}
\hline $\mathrm{S} / \mathrm{N}$ & Items & Min & Max & Mean & SD \\
\hline \multicolumn{6}{|c|}{ Teachers' Willingness to Teach CWSNs Cluster } \\
\hline$\overline{1}$ & $\begin{array}{l}\text { I am willing to teach behaviourally } \\
\text { challenging classes }\end{array}$ & 1.00 & 4.00 & 3.14 & .66 \\
\hline 2 & $\begin{array}{l}\text { I wouldn't mind teaching academically } \\
\text { weak children }\end{array}$ & 1.00 & 4.00 & 3.20 & .63 \\
\hline 3 & $\begin{array}{l}\text { I am prepared to teach the naughtiest } \\
\text { students }\end{array}$ & 1.00 & 4.00 & 2.96 & .82 \\
\hline 4 & I am ready to teach at-risk kids & 1.00 & 4.00 & 2.82 & .78 \\
\hline \multicolumn{6}{|c|}{ Teachers' Willingness for Emotional and Adaptive Support to CWSNs Cluste } \\
\hline 5 & $\begin{array}{l}\text { I am willing to encourage students with } \\
\text { disabilities to participate in all social } \\
\text { activities in the regular classroom }\end{array}$ & 1.00 & 4.00 & 3.31 & .66 \\
\hline 6 & $\begin{array}{l}\text { I am willing to adapt the curriculum to meet } \\
\text { the individual needs of all students } \\
\text { regardless of their ability }\end{array}$ & 1.00 & 4.00 & 3.37 & .64 \\
\hline 7 & $\begin{array}{l}\text { I am willing to include students with a } \\
\text { severe disability in the regular classroom } \\
\text { with the necessary support }\end{array}$ & 1.00 & 4.00 & 3.01 & .76 \\
\hline 8 & $\begin{array}{l}\text { I am willing to modify the physical } \\
\text { environment to include students with a } \\
\text { disability in the regular classroom }\end{array}$ & 1.00 & 4.00 & 3.09 & .72 \\
\hline 9 & $\begin{array}{l}\text { I am willing to adapt my communication } \\
\text { technique to ensure that all students with } \\
\text { emotional and behavioural disorders can be } \\
\text { successfully included in the regular } \\
\text { classroom }\end{array}$ & 1.00 & 4.00 & 3.29 & .71 \\
\hline 10 & $\begin{array}{l}\text { I am willing to adapt to the assessment of } \\
\text { individual students for inclusive education } \\
\text { to take place. }\end{array}$ & 1.00 & 4.00 & 3.31 & .63 \\
\hline
\end{tabular}

Table 3 depicts the mean responses of teachers on the two clusters. In cluster one, referring to teaching CWSNs, mean scores showed that teachers agreed that they were willing to teach these children in their regular classes. Items 3 and 4 had the lowest mean scores showing that teachers' willingness to teach the naughtiest and at-risk kids reduced.

Furthermore, teachers strongly agreed that they were willing to provide emotional support as well as to adapt the environment, curriculum, and assessment to include these children in their regular classes. The mean responses ranged from 3.01 to 3.37 . 
Table 4: T-test Statistic Table on Mean Differences according to Respondents' Gender and Marital Status in their Willingness to Teach and Provide Emotional and Adaptive Support for CWSNs

\begin{tabular}{|c|c|c|c|c|c|c|}
\hline Variables & Demographic & Mean & $\begin{array}{c}\text { Std. } \\
\text { Deviation }\end{array}$ & $\mathrm{t}$ & df & sign \\
\hline Teachers' willingness to teach & Male & 3.07 & .51 & .664 & 308 & .507 \\
\hline CWSNs & Female & 3.02 & .58 & & & \\
\hline Teachers' willingness to provide & Male & 3.26 & .49 & 481 & 307 & 631 \\
\hline $\begin{array}{l}\text { emotional and adaptive support } \\
\text { to CWSNs }\end{array}$ & Female & 3.23 & .51 & & & \\
\hline Teachers' willingness to teach & Married & 3.07 & .56 & 1.606 & 308 & .109 \\
\hline CWSNs & Single & 2.96 & .56 & & & \\
\hline Teachers' willingness to provide & Married & 3.22 & .52 & -.674 & 307 & .501 \\
\hline $\begin{array}{l}\text { emotional and adaptive support to } \\
\text { CWSNs }\end{array}$ & Single & 3.26 & .48 & & & \\
\hline
\end{tabular}

Table 4 shows that male teachers $(M=3.07, S D=.51)$ had a non-significant marginally higher mean score in willingness to teach CWSNs in regular classes than their female counterparts $(M=3.02, S D=.58), t(308)=.664, p>.05$. On teachers' willingness to provide emotional and adaptive support to CWSNs in their regular classes, male teachers $(M=3.26, S D=.49)$ had a non-significant marginally higher mean than their female counterparts $(M=3.23, S D=.51), t(307)$ $=.482, p<.05$.

Similarly, Table 4 shows that married teachers $(M=3.07, S D=.56)$ had a nonsignificant marginally higher mean score on willingness to teach CWSNs in regular classes than their unmarried counterparts $(M=2.96, S D=.56), t(308)=$ $1.606, p>.05$. On teachers' willingness to provide emotional and adaptive support to CWSNs in their regular classes, married teachers $(M=3.22$, $S D=.52)$ had a nonsignificant marginally lower mean score than their unmarried counterparts $(M=$ $3.26, S D=.48), t(307)=-.674, p<.05$. Results showed that gender and marital status did not significantly influence the teachers' willingness to teach and provide emotional and adaptive support to CWSNs in their regular classes.

Table 5: ANOVA Test on Differences in Teachers' Willingness to Include CWSNs in Regular Classes Based on Level of Years of Experience

\begin{tabular}{|c|c|c|c|c|c|c|c|c|}
\hline \multirow[t]{3}{*}{ Measure } & \multicolumn{6}{|c|}{ Level of years of experience } & \multirow[b]{3}{*}{$F(2,247)$} & \multirow[b]{3}{*}{ Sign. } \\
\hline & \multicolumn{2}{|c|}{$\begin{array}{l}\text { Mildly } \\
\text { experienced }\end{array}$} & \multicolumn{2}{|c|}{$\begin{array}{l}\text { Moderately } \\
\text { Experienced }\end{array}$} & \multicolumn{2}{|c|}{$\begin{array}{l}\text { Highly } \\
\text { experienced }\end{array}$} & & \\
\hline & $M$ & $S D$ & $M$ & $S D$ & $M$ & $S D$ & & \\
\hline $\begin{array}{l}\text { Teachers' Willingness to } \\
\text { Teach CWSNs }\end{array}$ & 3.03 & .62 & 3.00 & .48 & 3.16 & .51 & 1.869 & .156 \\
\hline $\begin{array}{l}\text { Teachers' Willingness for } \\
\text { Emotional and Adaptive } \\
\text { support to CWSNs }\end{array}$ & 3.25 & .49 & 3.20 & .51 & 3.32 & .50 & 1.014 & .364 \\
\hline
\end{tabular}

ANOVA statistics in Table 5 showed no significant main effect of teachers' levels of the years of experience on their willingness to teach CWSNs, $F(2,247)=1.869$, $p>.05$, or their willingness to provide emotional and adaptive support to CWSNs, 
$F(2,247)=1.014 p>.05$. Therefore, teachers' years of experience did not have a significant impact on their willingness to teach and provide emotional and adaptive support to CWSNs in their regular classes.

Table 6: ANOVA Test on Differences in Willingness to Include CWSNs in Regular Classes Based on Qualifications

\begin{tabular}{|c|c|c|c|c|c|c|c|c|}
\hline \multirow[t]{3}{*}{ Measure } & \multicolumn{6}{|c|}{ Highest Qualification } & \multirow[b]{3}{*}{$F(2,247)$} & \multirow[b]{3}{*}{ Sign } \\
\hline & \multicolumn{2}{|l|}{$\mathrm{NCE}$} & \multicolumn{2}{|c|}{ Degree } & \multicolumn{2}{|c|}{ M.Ed \& PhD } & & \\
\hline & $M$ & $S D$ & $M$ & $S D$ & $M$ & $S D$ & & \\
\hline $\begin{array}{l}\text { Teachers' Willingness to Teach } \\
\text { CWSNs }\end{array}$ & 2.88 & .64 & 3.07 & .54 & 2.96 & .63 & 1.60 & .204 \\
\hline $\begin{array}{l}\text { Teachers' Willingness for } \\
\text { Emotional and Adaptive } \\
\text { support to CWSNs }\end{array}$ & 3.08 & .48 & 3.25 & 3.25 & 3.37 & .54 & 2.52 & .082 \\
\hline
\end{tabular}

ANOVA statistics provided in Table 6 show no significant main effect of teachers' highest qualification on their willingness to teach CWSNs, $F(2,247)=1.60, p>.05$, or their willingness for emotional and adaptive support to CWSNs, $F(2,247), p$ $>$.05. Therefore, teachers' qualifications did not have a significant impact on their willingness to teach and provide emotional and adaptive support to CWSNs in their regular classes.

Table 7: ANOVA Test on Differences in Willingness to Include CWSNs in Regular Classes Based on Teacher Specialty

\begin{tabular}{|c|c|c|c|c|c|c|c|c|c|c|}
\hline \multirow[t]{4}{*}{ Measure } & \multicolumn{8}{|c|}{ Specialty } & \multirow[b]{4}{*}{$F(2,247)$} & \multirow[b]{4}{*}{ Sign } \\
\hline & \multirow{2}{*}{\multicolumn{2}{|c|}{$\begin{array}{l}\text { Arts } \\
\text { Education }\end{array}$}} & \multirow{2}{*}{\multicolumn{2}{|c|}{$\begin{array}{l}\text { Soc. Science } \\
\text { Education }\end{array}$}} & \multirow{2}{*}{\multicolumn{2}{|c|}{$\begin{array}{l}\text { Science } \\
\text { Education }\end{array}$}} & \multirow{2}{*}{\multicolumn{2}{|c|}{$\begin{array}{l}\text { Business } \\
\text { Education }\end{array}$}} & & \\
\hline & & & & & & & & & & \\
\hline & $M$ & $S D$ & $M$ & $S D$ & $M$ & $S D$ & $M$ & $S D$ & & \\
\hline $\begin{array}{l}\text { Teachers' Willingness to } \\
\text { Teach CWSNs }\end{array}$ & 3.07 & .56 & 3.04 & .53 & 3.11 & .60 & 2.75 & .45 & 3.86 & .010 \\
\hline $\begin{array}{l}\text { Teachers' Willingness } \\
\text { for Emotional and } \\
\text { Adaptive Support to } \\
\text { CWSNs }\end{array}$ & 3.23 & .57 & 3.24 & .48 & 3.32 & .46 & 3.24 & .50 & 2.43 & .066 \\
\hline
\end{tabular}

ANOVA statistics in Table 7 show that teacher specialty had a significant main effect on their willingness to teach CWSNs, $F(2,247)=3.86, p<.05$, and their willingness for emotional and adaptive support to CWSNs, $F(2,247)=2.43 p>.05$. Posthoc analyses using the Bonferroni test indicated significant differences in teachers' willingness to teaching CWSNs among teachers who specialized in science education and those who specialized in business education $(p .<.05)$; and also between those in arts education and business education $(p<.05)$. Therefore, teachers' specialty had a significant impact on their willingness to teach, while it did not have a significant impact on teachers' willingness to provide emotional and adaptive support to CWSNs in their regular classes. 


\section{Discussion}

Our study was aimed at investigating Nigerian teachers' willingness to include CWSNs in their regular classes and how their socio-demographics could impact their inclusive education willingness. This was informed by the fact that some teachers in Nigeria, despite the global trend towards educating CWSNs in inclusive education settings, are still not so receptive to the idea of inclusion. For effective implementation of inclusive education in Nigeria, there must be teachers who have not just received training in inclusive education but also teachers who are willing to accept CWSNs in their classes. This becomes significant, given that teachers are the bedrock for inclusive education implementation (Cate et al., 2018).

Our findings indicated that teachers were willing to teach and provide a supportive environment for CWSNs in their classes. This was manifested in the high mean scores in the responses. Teachers also were more willing to provide a supportive environment than to teach CWSNs. This might have been informed by their perception of what CWSNs needed most. Granted is the fact that for effective teaching of CWSNs in regular classes, there must be emotional and adaptive support in which the teachers will be empathic to the students. Researchers are of the view that support and adaptation are very important in inclusive education, and that inclusive education demands such competencies to be developed and nurtured among the general teachers (Buli-Holmberg \& Jeyaprathaban, 2016). Teachers must also be willing to adjust their instructional approaches, curriculum, and assessment practices to accommodate CWSNs.

A closer examination of the mean scores revealed lower scores in teachers' willingness to teach students with behavioural problems and at-risk students. Teachers might have their reservations about this group of students. Also, at-risk students are more demanding and teachers might have been cautious in their responses here. This aligns with research that shows that the nature of a disability may affect the way and manner in which the teacher may be receptive to the child (Cassady, 2011). There is the tendency among teachers to be willing to teach children they perceive to have the competence to handle, since this has been shown to influence teachers' receptivity of CWSNs in their classes (Cate et al., 2018).

Findings on teachers' socio-demographics showed non-significant effects on their willingness to include children in the classes, except for teacher specialty. Concerning gender, male teachers had a non-significant marginally higher mean score for their willingness to teach and provide emotional and adaptive support to CWSNs in regular classes than their female counterparts. Thus, this study accepts the null hypothesis that teachers' willingness to teach CWSNs and provide emotional and adaptive support for them in their regular classes do not significantly differ as a result of their gender, marital status, experience, and specialty. Our finding contradicts several similar studies that have shown that female teachers are more inclined to inclusive education practices, stating that they are more patient with CWSNs (Dev \& Kumar, 2015). Our findings showed that both male and female teachers were willing to include CWSNs in their classes. The difference in the mean responses could have been by chance, since it is not statistically significant. 
Based on the findings, teachers' marital status had no significant impact on their willingness to teach CWSNs in regular classes, though those who were married were a little bit more willing than their unmarried counterparts. On teachers' willingness to provide emotional and adaptive support to CWSNs in their regular classes, married teachers had a non-significant marginally lower mean than their unmarried counterparts. Though our finding is not statistically significant, it shows that married teachers are more willing to teach CWSNs, while teachers who are not married are more willing to provide emotional and adaptive support. Current literature shows extremely limited studies on marital status and inclusive education practice. Thus, there is currently very little empirical evidence that teachers who are married may be more willing to engage with children than their unmarried counterparts, given that having children has a way of mellowing teachers (Odanga, Aloka, \& Raburu, 2015).

Our findings indicated that the level of years of teaching experience had no significant impact on teachers' willingness to include CWSNs in regular classes. This contradicts the findings of similar studies such as those of Dea and Negassa (2019) and Dev and Kumar (2015), that showed that teachers' years of experience was a significant factor in inclusive education practice such as collaboration with other professionals and their perception of inclusive education.

Furthermore, teachers' highest qualifications did not have a significant impact on their willingness to teach and provide emotional and adaptive support to CWSNs in their regular classes. This implies that regardless of the qualifications with which the teachers sampled for this study were teaching with, they were all willing to include CWSNs in their classes. This may be the opposite of the common assumption that the higher their qualifications the more willing teachers may be to participate in inclusive education practices. However, exposure to compulsory courses in inclusive education could close the gap that might be generated by differences in qualifications. Song et al. (2019) found that the completion of a compulsory course in inclusive education improved teachers' competencies in inclusive education practice.

In our study it was found that teachers' specialty had a significant impact on their willingness to teach CWSNs in their regular classes, while it did not have a significant impact on their willingness to provide emotional and adaptive support to CWSNs in their regular classes. Posthoc analyses showed the significant differences in teachers' willingness to teaching CWSNs occurred among teachers who specialized in science education and those who specialized in business education; and between those in arts education and business education. Similar studies have shown that the area of study of a teacher could affect teacher inclusive education practice. Dea and Negassa (2019) found that teachers with a specialty in special education practise more individualized teaching than those who have not had special education training. It could be that the knowledge a teacher has concerning CWSNs could influence his/her willingness to teach them. Therefore, specialty areas that could expose the teacher to underlying biological and environmental factors affecting CWSNs, are likely to impact teachers' receptivity of CWSNs in regular classes. It might be that the fields of sciences and arts could impact on teachers' willingness to accept CWSNs in their classroom rather than the specialty area of business education, as those teachers in sciences 
might have been more informed about the biological issues related to disabilities. Teachers that majored in the arts might be more susceptible to exhibiting a humanistic approach to teaching CWSNs.

\section{Conclusion and Limitations}

Our study has made significant contributions to understanding which factors might impact teachers' willingness to include CWSNs in regular classes in Nigeria. This appears to be the first study that has examined the teachers' sociodemographic variables that might have an effect on their willingness to include CWSNs in their regular classes within the Nigerian context. Taking cognisance of these variables may influence policies regarding training and retraining teachers for inclusive education in Nigeria.

Our study showed that teachers in Nigeria reported that they are willing to include CWSNs in their regular classes and that their sociodemographic characteristics did not impact their willingness significantly, except in the case of their specialty. It was concluded that aspects of the teacher socio-demographic variables that may affect their willingness to include CWSNs are those that could influence their competence.

This has significant implications for the implementation of inclusive education in Nigeria. Since the teachers are willing to include CWSNs in regular classes, a need exists for the logistics to be finalised and for further training of teachers and others involved to ensure that effective inclusive education is implemented and maintained in Nigeria. This will make available education that can cater for the needs of all Nigerian children. The finding that only the area of specialty resulted in significant differences in teachers' willingness to include CWSNs in regular classes implies that the teacher education curriculum should be reviewed to ensure that irrespective of a student teacher's area of specialization, content should be included in the curriculum that will ensure that teachers are prepared and willing to include CWSNs in their regular classes.

Granted, our study has made a significant contribution to the literature on inclusive education, but still it was limited by specific factors. First, an exclusively quantitative research approach was used; results could have been substantiated if there was a possibility of triangulation of findings. For more robust findings, future studies should adopt both quantitative and qualitative designs. Second, the majority of our respondents were female teachers which could ensue data bias. The generalization of this finding to areas without such a lopsided teacher population concerning gender, may be difficult. We believe this study provided a sound starting-point for further work on the issue if inclusive education in African schools, as it emphasised the importance of teachers' attitude to educational approaches, and more specifically education for CWSNs.

\section{References}

Abdullahi, K.B. (2019). Socio-demographic status: Theory, methods and applications. Preprints. doi:10.20944/preprints201902.0051.v1

Adebisi, R. O., Jerry, J. E., Rasaki, S. A., \& Igwe, E. N. (2014). Barriers to special needs education in Nigeria. International Journal of Education and Research, 2(11), 451-462. 
Amadi, E. C., \& Allagoa I. C. (2017). Demographic variables as determinants of teachers'effectiveness in classroom management in secondary schools in Rivers State, Nigeria. International Journal of Innovative Development \& Policy Studies, 5(4), 65-70.

Boyd, W. C. (2017). The perspectives of special education teachers on students with disabilities in an inclusion setting. Doctoral Dissertation, Carson-Newman University. Retrieved from https://www.cn.edu/libraries/tiny_mce/tiny_mce/plugins/filemanager/files /Disserations Dissertaions Fall2017/Waldrian_Coleman_Boyd.pdf

Braunsteiner, M- L., \& Mariano-Lapidus, S. (2014). A perspective on inclusion: Challenges for the future. Global Education Review, 1(1), 32-43. Retrieved from https://files.eric.ed.gov/fulltext/EJ1055217.pdf

Buli-Holmberg, J., \& Jeyaprathaban, S. (2016). Effective practice in inclusive and special needs education. International Journal of Special Education, 31(1), 119-134.

Cassady, J. M. (2011). Teachers' attitudes toward the inclusion of students with autism and emotional behavioral disorder. Electronic Journal for Inclusive Education, 2(7), 1-24. Retrieved from https://corescholar.libraries.wright.edu/ejie/vol2/iss7/5/

Cate, I. M. P., Markova, M., Krischler, M., \& Krolak-Schwerdt, S. (2018). Promoting inclusive education: The role of teachers' competence and attitudes. Insights into LearningDisabilities, 15(1), 49-63. Retrieved from https://eric.ed.gov/?id=EJ1182863.

Chao, C. N. G., Sze, W., Chow, E., Forlin, C., \& Ho, F. C. (2017). Improving teachers' selfefficacy in applying teaching and learning strategies and classroom management to students with special education needs in Hong Kong. Teaching and Teacher Education, 66, 360-369. doi:10.1016/j.tate.2017.05.004

Dea, P., \& Negassa, D. (2019). The influence of demographic factors on teachers' instructional practices and challenges in including students with visual impairment in government secondary schools of Harari Region. International Journal of Education \& Literacy Studies, 7(3), 19-27. doi:10.7575/aiac.ijels.v.7n.3p.19

Dev, S., \& Kumar, J. (2015). Teachers' perception towards integration of learning disabled students into a regular class room: A study in Dubai \& Abu Dhabi Schools. Procedia Social and Behavioral Sciences, 211, 605-611. doi:10.1016/j.sbspro.2015.11.079

Dudley-Marling, C., \& Burns, M.B. (2014). Two perspectives on inclusion in the United States. Global Education Review, 1(1), 14-31. Retrieved from https://files.eric.ed.gov/fulltext/EJ1055208.pdf

Efanga, S. I., Ikpe, U. G., \& Idante, G. O. (2014). Influence of demographic variables on teachers' willingness to stay on in the teaching profession in Akwa Ibom State of Nigeria. International Journal of Humanities, Social Sciences and Education (IJHSSE), 1(10), 41-46. Retrieved from https://www.arcjournals.org/pdfs/ijhsse/v1i10/7.pdf

Ellis, D. (2011). Impact of teacher demographic, knowledge, and instructional variables on children's language development. (Doctoral Dissertation, University of North Florida). Retrieved from https://digitalcommons.unf.edu/etd/383

Eskay, M., Eskay, O., \& Uma, E. (2012). Educating people with special needs in Nigeria: Present and future perspectives. US-China Education Review B, 10, 898-906. Retrieved from https://files.eric.ed.gov/fulltext/ED537995.pdf

Fraenkel, J. R., \& Wallen, N. E. (2000). How to design and evaluate research in education. Boston: McGraw-Hill Companies, Inc. 
Greene, B. L. (2017). Teachers' attitudes toward inclusive classrooms. Doctoral Dissertation, Walden University. Retrieved from https://scholarworks.waldenu.edu/dissertations/3445/

Gilor, O., \& Katz, M. (2018). Pre-service teachers' willingness to engage in inclusive teaching: An explanatory model. Journal of International Special Needs Education, 113.

Global Partnership for Education. (2018). Disability and inclusive education: A stock take of Education Sector Plans and GPE-Funded grants. GPE: USA. Retrieved from: https://www.globalpartnership.org/sites/default/files/2018-04-23gpedisability-and inclusive-education_0.pdf

Igbo, J. N., Obiyo, N. O., Onu, V. C., \& Eskay, M. K. (2014). Special education services in Nigeria: Psychological implications for Nigerian education system. Nsukka Journal of the Humanities, 22(2), 201-2010. Retrieved from https://oer.unn.edu.ng/read/nsukka journal-of-the-humanities-vol-22-no2special-education-services-in-nigeria-psychological-implications-for-nigerianeducation-system/file.pdf

LaVergne, D. D., Jones, W. A., Larke, A. Jr., \& Elbert, C. D. (2012). The effect of teacher demographics and personal characteristics on perceptions of diversity inclusion in agricultural education programs. Journal of Agricultural Education, 53(3), 84-97. doi:10.5032/jae.2012.03084

Limaye, S. (2016). Factors influencing the accessibility of education for children with disabilities in India. Global Education Review, 3(3), 43-56. Retrieved from https:// files.eric.ed.gov/fulltext/EJ1115090.pdf

Low, E., Ng, P., Hui, C., \& Cai, L. (2019). How do teacher affective and cognitive selfconcepts predict their willingness to teach challenging students? Australian Journal of Teacher Education, 44(10), 18-34. Retrieved from https://ro.ecu.edu.au/ajte/vol44/iss10/2

Mahat, M. (2008). The development of a psychometrically-sound instrument to measure teachers' multidimensional attitudes toward inclusive education. International Journal of Special Education, 23(1), 82-92.

Obisesan, O. E. (2020). Teacher attitudes, cultural beliefs, and problems experienced teaching children with disabilities in Nigeria. (Master's Thesis, University of Jyvaskyla). Retrieved from https://jyx.jyu.fi/bitstream/handle/123456789/68351/1/URN\%3ANBN\%3Afi \%3Ajyu 202003302562.pdf.

Odanga, S. J. O., Aloka, P. J. O., \& Raburu, P. (2015). Influence of marital status on teachers' self-efficacy in secondary schools of Kisumu County, Kenya. Academic Journal of Interdisciplinary Studies, 4(3), 115-124. doi:10.5901/ajis.2015.v4n3p115

Oladele, A. O., Ogunwale, O. R., \& Dafwat, S. S. (2016). Inclusive education for persons with disabilities in Nigeria: How far? International Journal of Advanced Academic Research in Arts, Humanities \& Education, 2(5), 1-8. Retrieved from http://www.ijaar.org/articles/volume2-number5/Arts-Humanities-

Education/ijaarahe v2n5 may16-p3.pdf

Oluremi, F. D. (2015a). Inclusive education setting in Southwestern Nigeria: Myth or reality? Universal Journal of Educational Research, 3(6), 368-374. doi:10.13189/ujer.2015.030603.

Oluremi, F. D. (2015b). Attitude of teachers to students with special needs in mainstreamed public secondary schools in Southwestern Nigeria: The need for a change. European Scientific Journal, 11(10), 194-209. Retrieved from http://eujournal.org/index.php/esj/article/view/5419 
Onukwufor, J. N., \& Martins, U. (2017). Challenges of implementing inclusive education of children with visual impairment in Port Harcourt, Rivers State. International Journal of Education, Learning and Development, 5(3), 1-9. Retrieved from https://oapub.org/edu/index.php/ejes/article/view/2435

Rochon, J., Gondan, M., \& Kieser, M. (2012). To test or not to test: Preliminary assessment of normality when comparing two independent samples. BMC Medical Research Methodology, 12(81), 1-11. Retrieved from http://www.biomedcentral.com/1471 $2288 / 12 / 81$

Rughinis, C., \& Huma, B. (2015). Who theorizes age? The "Socio-Demographic Variables" device and age-period-cohort analysis in the rhetoric of survey research. Journal of Aging Studies, 35, 144-159. doi:10.1016/j.jaging.2015.07.005

Schuelka, M. J., \& Johnstone, C. J. (2011). Global trends in meeting the educational rights of children with disabilities: From international institutions to local responses. Retrieved from https:/ / www.researchgate.net/publication/280860309

Shaukat, S. (2012). Impact of demographic variables in the development of prospective teachers' efficacy beliefs towards inclusive practices in the context of Pakistan. The European Journal of Social $\mathcal{E}$ Behavioural Sciences, 484-508. doi:10.15405/FutureAcademy/ejsbs(2301-2218).2012.3.9

Song, J., Sharma, U., \& Choi, H. (2019). Impact of teacher education on pre-service regular school teachers' attitudes, intentions, concerns and self-efficacy about inclusive education in South Korea. Teaching and Teacher Education, 86, 1-9. doi:10.1016/j.tate.2019.102901

Stockemer, D. (2019). Quantitative methods for the social sciences: A practical introduction with examples in SPSS and Stata. Switzerland: Spinger International Publishing AG. doi:10.1007/978-3-319-99118-4

Unachukwu, G. C., \& Nwosu, K. C. (2019). Considerations in inclusive education in West Africa: What challenges really exist? Journal of the Nigerian Academy of Education (Special Edition), 15(1), 34-53. Retrieved from https://journals.ezenwaohaetorc.org/index.php/JONAED/article/download/ 1304/1 46

VanderStel, A. (2014). The impact of demographics on education. Honors Projects, Grand Valley State University. $\quad$ Retrieved from https://scholarworks.gvsu.edu/honorsprojects/329

\section{Appendix A}

\section{Section A: Bio-data}

Please respond to the following by ticking $(\sqrt{ })$ in the boxes provided below as the items describe you.

Gender: Male $\square$ Female $\square$

Marital Status: Married $\square \quad$ Single $\square \quad$ Widowed $\square$

Year of Experience

Highest Qualification: NCE $\square$ Ph.D $\square$

B.ED/BA/B.Sc $\square$ M.Ed/MA/M.Sc $\square$

Area of Specialization: Arts Education $\square$ Social Science Education $\square$ Science $\square$ Education $\square$ 


\section{Business Education}

Section B: Teacher Willingness to Include CWSNs Questionnaire (TWICWSNsQ)

Instruction: Respond to the following items to indicate how willing you are to teach children with special needs in your class by $(\sqrt{ })$ in the responses provided.

\begin{tabular}{|l|l|l|l|l|l|}
\hline S/N & \multicolumn{1}{|c|}{ Items } & SA & A & D & SD \\
\hline Teachers' Willingness to Teach CWSNs Cluster & & & & \\
\hline 1 & $\begin{array}{l}\text { I am willing to teach behaviourally challenging } \\
\text { classes }\end{array}$ & & & & \\
\hline 3 & $\begin{array}{l}\text { I wouldn't mind teaching academically weak } \\
\text { children }\end{array}$ & & & & \\
\hline 4 & I am prepared to teach the naughtiest students & & & & \\
\hline $\begin{array}{l}\text { Teachers' Willingness for Emotional and Adaptive } \\
\text { Support for CWSNs Cluster }\end{array}$ & & & & \\
\hline 5 & $\begin{array}{l}\text { I am willing to encourage students with } \\
\text { disabilities to participate in all social activities in } \\
\text { the regular classroom }\end{array}$ & & & & \\
\hline 6 & $\begin{array}{l}\text { I am willing to adapt the curriculum to meet the } \\
\text { individual needs of all students regardless of } \\
\text { their ability }\end{array}$ & & & & \\
\hline 7 & $\begin{array}{l}\text { I am willing to include students with a severe } \\
\text { disability in the regular classroom with the } \\
\text { necessary support }\end{array}$ & & & & \\
\hline 8 & $\begin{array}{l}\text { I am willing to modify the physical environment } \\
\text { to include students with a disability in the } \\
\text { regular classroom }\end{array}$ & & & & \\
\hline 9 & $\begin{array}{l}\text { I am willing to adapt my communication } \\
\text { technique to ensure that all students with } \\
\text { emotional and behavioural disorders can be } \\
\text { successfully included in the regular classroom } \\
\text { individual students for inclusive education to } \\
\text { take place. }\end{array}$ & & & & \\
\hline 10 & am willing to adapt to the assessment of & & & \\
\hline
\end{tabular}

